
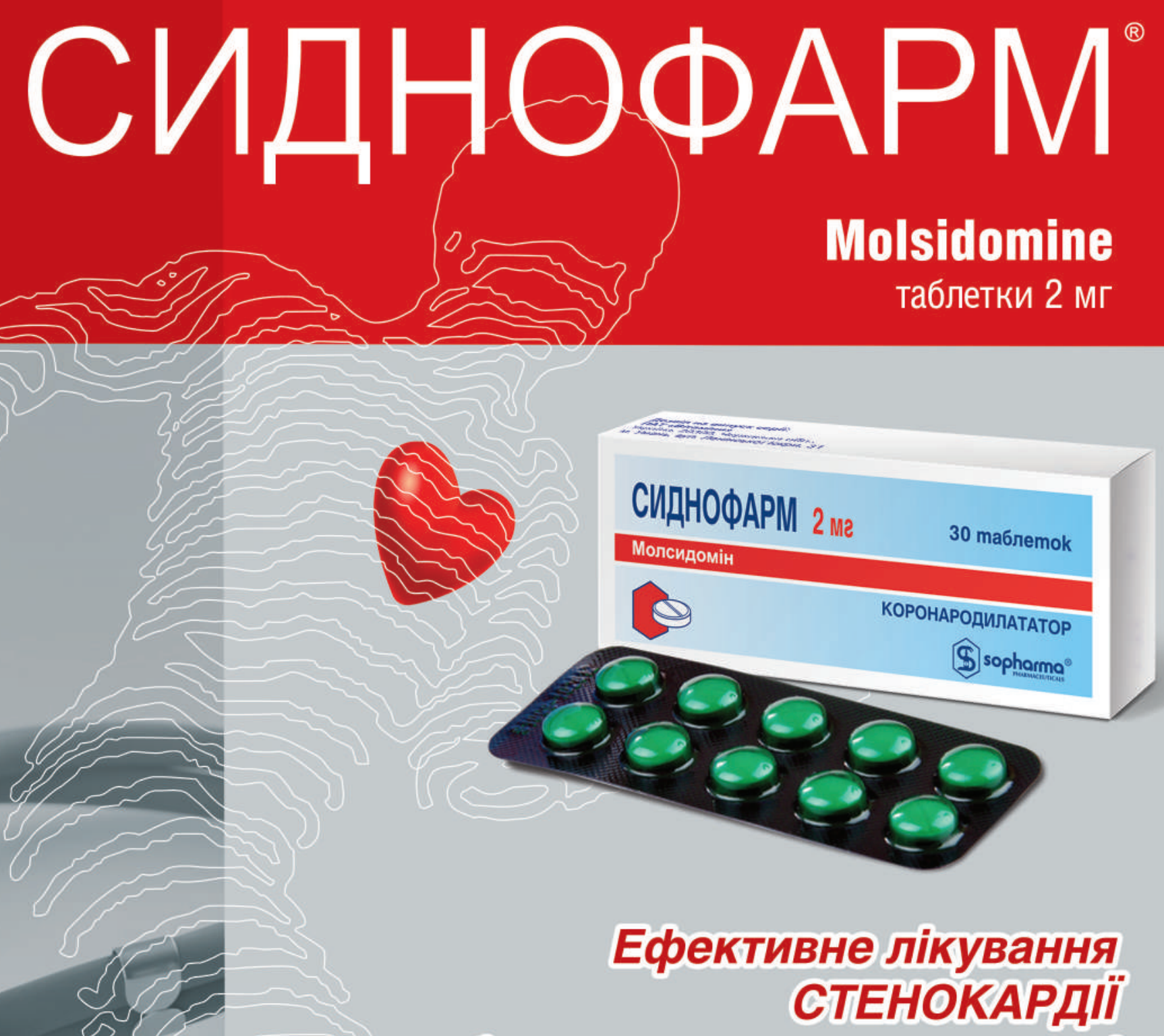

без розвитку толерантності
( Зменшує частоту нападів стенокардії'
- Підвищує толерантність до фізичного навантаження'
○ Не викликас звикання при тривалому застосуванні ${ }^{2}$ 


\title{
Постковідні зміни в структурі серця й ефективність вазодилататора Сиднофарм (результати власного дослідження)
}

\author{
Н.Ю. Осовська, Л.А. Олійник \\ Вінницький національний медичний університет імені М.І. Пирогова, Вінниця, Україна
}

\begin{abstract}
Анотація. Мета: порівняння змін структурно-функціонального стану міокарда лівого шлуночка у пацієнтів після перенесеного COVID-19 та визначення антиангінальної й антиішемічної активності молсидоміну (Сиднофарм) у цієї категорії пацієнтів. Об'єкт $і$ методи дослідження. Обстежено 120 осіб віком 58土8,23 року (48,4\% жінок та 51,6\% чоловіків), 60 з яких перехворіли на COVID-19 і мали скарги з боку серцево-судинної системи, зокрема кардіалгію. Усі пацієнти у комплексному лікуванні основних захворювань отримували статини, блокатори ренін-ангіотензин-альдостеронової системи, антиагреганти та іншу призначену терапію. Пацієнтів, що перехворіли на COVID-19, розділили на дві рівні групи (по 30 осіб). В 1-й (основній) групі в програму лікування доданий Сиднофарм в дозі 2 мг 2 рази на добу протягом 1 міс, 2-га (група порівняння) отримувала будь-які антиангінальні лікарські засоби, крім нітратів пролонгованої дії. Результати. Встановлено, що пацієнти, що перенесли COVID-19 протягом останніх 6 міс, мають відносно більші об'єми лівих відділів серця та масу міокарда лівого шлуночка порівняно з тими, що не перехворіли. У них спостерігається відносна гіперсимпатикотонія з переважанням денної аритмічної активності. За даними спекл-трекінг ехокардіографії, у пацієнтів, що перенесли COVID-19 та мають тривалий час кардіалгію, спостерігається зменшення локальної скоротливості переважно базальних сегментів стінок лівого шлуночка внаслідок субендокардіальної мікроваскулярної ішемії. У пацієнтів із постковідною кардіалгією виявлено суттєве зменшення, як вираженості скарг, так і інструментальних даних проявів ішемії: кількості епізодів депресії сегменту ST (згідно з даними холтерівського моніторингу електрокардіограми) та покращення скоротливості переважно базальних та середніх відділів стінок лівого шлуночка (за даними спекл-трекінг ехокардіографії) внаслідок покращення їх кровопостачання на тлі лікування Сиднофармом в дозі 2 мг 2 рази на добу протягом 30 днів. Висновок. Сиднофарм - коронародилататор, донатор оксиду азота, ендотеліопротектор, антиангінальний та антиішемічний препарат, який застосовують переважно в лікуванні ішемічної хвороби серця, - можна рекомендувати призначати також в комплексній терапії пацієнтів із постковідним синдромом.
\end{abstract}

Ключові слова: COVID-19, постковідний синдром, кардіалгія, молсидомін, Сиднофарм.

\section{Вступ}

Станом на 13.05 .2021 р. у світі зареєстровано $>160,4$ млн, в тому числі в Україні - >2,19 млн випадків COVID-19 [1]. Очевидних провісників закінчення епідемії немає, хоча активно розпочалася вакцинація. Світ накрила інша хвиля - хвиля постковідного синдрому. Тривалі соматичні скарги підтримуються персистуючою тривогою.

Вірусне ураження, цитокіновий шторм, гіперкоагуляція, гіперактивація симпатоадреналової та ренін-ангіотензин-альдостеронової (РААС) систем, гострий респіраторний дистрес-синдром, прямий цитотоксичний ефект вірусу на кардіоміоцити, бактеріальна інфекція зумовлюють виникнення тотального ендотеліїту, тромбозів коронарних судин, розриву та тромбозу атеросклеротичних бляшок, призводять до гострого коронарного синдрому, гострої серцевої недостатності, загострення хронічної серцевої недостатності [2, 3].

Чи існує класичний міокардит при гострому перебігу хвороби? На сьогодні дані суперечливі: наявність запальної інфільтрації міокарда Т-лімфоцитами та макрофагами, осередки некрозу та крововиливи в міокарді свідчать на користь міокардиту; пошкодження тільки окремих кардіоміоцитів, одиничні лімфоцити у стромі та стінках судин та відсутність доказів про реплікацію вірусу у кардіоміоцитах більше на користь відсутності дифузного запалення серцевого м'яза $[4,5]$.

Патофізіологія персистенції постковідних змін знаходиться в стадії вивчення. Зміни переважно в ендотелії (ендотеліїт, ендотеліальна дисфункція) обумовлені характером ушкодження органів в гострій фазі інфікування, особливостями стійкого гіперзапального процесу, триваючою вірусною активністю, що пов'язана 3 наявністю вірусного резервуару та неадекватною аутоімунною відповіддю [6-12].

Ендотелій остаточно визнаний ахіллесовою п'ятою при COVID-19 у гострий та постковідний періоди, $\epsilon$ основою постковідного синдрому та синдрому «постковідного далекобійника» [2]. Вірус потрапляє в організм через ендотелій, реплікується в ендотелії, аутоімунна реакція також «б'є» по ендотелію, спричиняючи як поліорганну патологію, так і синдром гіперкоагуляції $[6,7]$.

Основою терапії пацієнтів після COVID-19 визнано лікування основних захворювань та зменшення вираженості ознак персистуючого запалення ендотелію та ендотеліальної дисфункції [5, 13-15].

Визнаними проявами ендотеліальної дисфункції вважають:

1. Порушення біодоступності оксиду азоту (NO) через пригнічення експресії/інактивації ендотеліальної NO-синтази і зниження синтезу NO; зниження щільності на поверхні ендотеліоциту рецепторів, подразнення яких у нормі призводить до утворення NO; підвищення деградації NO - руйнування NO настає раніше, ніж речовина досягне свого місця дії.

2. Підвищення активності ангіотензинперетворювального ферменту на поверхні ендотеліоцитів.

3. 3більшення синтезу ендотеліоцитом ендотеліну-1 та інших вазоконстрикторних субстанцій.

4. При тяжкому ураженні ендотелію порушується його цілісність і в інтимі з'являються ділянки, позбавлені ендотеліальної вистилки (деендотелізація); це призводить до того, що нейрогормони, оминаючи ендотелій і, тим самим, безпосередньо взаємодіючи з гладком'язовими клітинами, зумовлюють їх скорочення.

У цьому контексті особливого значення набувають лікарські засоби, які впливають саме на функцію ендотелію. Статини демонструють різноманітні плейотропні ефекти позитивного впливу на ендотелій і можуть сприятливо діяти на згортання крові та активацію тромбоцитів. Блокатори РААС покращують дисфункцію ендотелію і також мають певні антикоагулянтні властивості, знижуючи експресію тканинного фактора в ендотеліальних клітинах. Сьогодні вважається за доцільне продовжувати прийом інгібіторів ангіотензинперетворювального ферменту та/або блокатори рецепторів ангіотензину II у пацієнтів із COVID-19, якщо вони отримували ці лікарські засоби за показаннями [16]. Коректним та патогенетично 
обгрунтованим вбачається лікування постковідних проявів безпосередніми донорами NO.

Серед препаратів, що заслуговують на особливу увагу саме у пацієнтів із постковідною кардіалгією, - донор молекули NO молсидомін. Він чинить потрійну дію: антиангінальну, венодилататорну, антиагрегантну. Також молсидомін сприятливо впливає на переднавантаження та метаболізм міокарда, в результаті чого потреба в кисні різко знижується. Крім того, молсидомін збільшує діаметр субендокардіальних судин, покращує коронарний кровообіг та забезпечує міокард киснем, що, в свою чергу, підвищує толерантність до фізичних навантажень. Отже, серед переваг молсидоміну - його висока ефективність для захисту серця від болю, прекрасний профіль безпеки та гарантія терапевтичної ефективності протягом тривалого застосування. Відсутність розвитку толерантності до активної речовини суттєво відрізняє молсидомін від інших нітратоподібних лікарських засобів. Молсидоміну притаманний позитивний гемодинамічний ефект зменшення постнавантаження на серце. Завдяки цьому нормалізується внутрішньосерцева гемодинаміка, а саме: зменшується наповнення лівого шлуночка (ЛШ) і напруга стінки міокарда, знижується тиск у легеневій артерії, що сприяє зниженню ступеня первинної або вторинної дилатації порожнин серця. Окрім того, молсидомін пригнічує ранню фазу агрегації тромбоцитів, знижує виділення і синтез серотоніну, тромбоксану та інших проагрегантів [17].

Мета дослідження - порівняння змін структурно-функціонального стану міокарда ЛШ у пацієнтів після перенесеного COVID-19 та визначення антиангінальної й антиішемічної активності молсидоміну (Сиднофарм) у цієї категорії пацієнтів.

\section{Об'єкт і методи дослідження}

На І етапі дослідження обстежено 120 осіб віком 58ะ8,23 року (48,4\% жінок та 51,6\% чоловіків), 603 яких перехворіли на COVID-19 і мали скарги з боку серцево-судинної системи, зокрема кардіалгію. Групи були зіставні за віком, статтю та коморбідністю. Усі пацієнти у комплексному лікуванні основних захворювань отримували статини, блокатори РАAC, антиагреганти та іншу призначену терапію.

Критерій включення: кардіалгія, що виникла або посилилася протягом наступних 6 міс після перенесеного COVID-19.

У дослідження не включали пацієнтів із неконтрольованою артеріальною гіпертензією, після перенесеного інфаркту міокарда та реваскуляризації, з високим класом стенокардії (III-IV), нестабільною стенокардією, декомпенсованими хворобами нирок та печінки та хворих, які мали тяжкий перебіг COVID-19.

На II етапі пацієнтів, що перехворіли на COVID-19, розділили на дві рівні групи (по 30 осіб). В 1-й (основній) групі в програму лікування доданий Сиднофарм в дозі 2 мг 2 рази на добу протягом 1 міс, 2-га (група порівняння) отримувала будь-які антиангінальні лікарські засоби, крім нітратів пролонгованої дії. Нітрати виключали через подібний механізм дії та високу вірогідність швидкого розвитку толерантності.

Основними методами інструментального обстеження були ехокардіографія (ЕхоКГ), холтерівське моніторування електрокардіограми (хмЕКГ), спекл-трекінг ЕхоКГ (СТЕхоКГ).

Відбіркове ультразвукове дослідження та СТЕхоКГ виконували на ехокардіографі «Vivid 7» (США). Для оцінки стану ЛШ та систолічної функції визначали кінцево-систолічний (КСР, КСО) та кінцево-діастолічний розміри та об'єми (КДР, КДО), товщину міжшлуночкової перегородки (ТМШПд) та задньої стінки ЛШ в діастолу (ТЗСЛШд), поперечний розмір лівого передсердя (ЛП). Розраховували масу міокарда ЛШ (ММЛШ) та її індекс.

хмЕКГ проводили в амбулаторних умовах за допомогою апарату «Діакард» моделі 3225 (АОЗТ «Сольвейг», Україна). Визначали такі показники: середню добову частоту серцевих скорочень (ЧСС), циркадний індекс (ЦІ), загальну кількість шлуночкових (ШЕ) та надшлуночкових екстрасистол (НШЕ) за добу, їх співвідношення в активний і пасивний періоди (ШЕд/ШЕн, НШЕд/
НШЕн), наявність, кількість, сумарну тривалість та максимальну тривалість епізоду депресії сегмента ST.

Основні дані, що пояснюють сутність методики СТЕхоКГ, представлені у табл. 1 та 2. Цей метод із фізичним навантаженням був основним методом реєстрації ішемії до та після лікування. СТЕхоКГ проводили у пацієнтів, які перенесли COVID-19, та без COVID-19 в анамнезі для з'ясування особливостей «постковідного серця», а також для визначення ефективності Сиднофарму відносно кардіалгії та ішемії. Зміни стрейну визначали за 17 сегментами, які представлені на схемі-«мішені» та відображували скоротливість цих зон ЛШ.

Статистичну обробку результатів проводили за допомогою методів варіаційної статистики з використанням програми «StatSoft», «Statistica» v. 12.0. У зв'язку з наявністю неправильного (негаусівського) розподілу, визначеного за допомогою критерію Колмогорова - Смірнова, для більшості показників отримані результати представлені наступним чином: кількісні величини - у вигляді медіани та інтерквартильного розмаху (25-й і 75-й процентилі); відносні величини (відображали частоту ознаки у виборці) у вигляді відсотків (\%). Порівняння відносних величин (\%) проводили за допомогою критерію $c^{2}$, кількісних величин незалежних виборок - за критерієм Манна - Уітні та Kruskal - Wallis ANOVA \& Median test.

Таблиця 1 Пояснення сутності методики СТЕхоКГ (1)

СТЕхоКГ — неінвазивна
коронарографія у пацієнтів
із кардіалгією

- Недопплерівська методика, яка дозволяє ефективно аналізувати і виявляти міокардіальну патологію за допомогою спеціального програмного пакета, здатного аналізувати деформацію міокарда за допомогою відстеження руху відблисків (англ. speckle) міокардіального сигналу.

- Відповідно до трьох шарів міокарда і типів деформації розрізняють циркулярну, поперечну (або радіальну) і поздовжню деформацію. Радіальний поперечний стрейн добре відбивається ФB.

- Поздовжня деформація (англ. Iongitudinal strain) відображає саме поздовжню скоротність субендотеліального шару міокарда, який уражується на самих ранніх стадіях будь-якої кардіальної патології

Таблиця 2 Пояснення сутності методики СТЕхоКГ (2)

Ішемічний патерн: до та після стентування передньої міжшлуночкової гілки

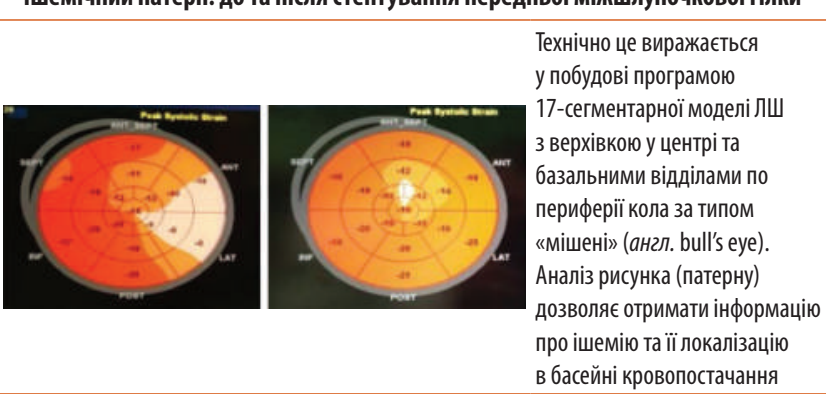

Кількісно поздовжній стрейн оцінюеться у відсотках і в нормі має негативну величину, оскільки «спекли» міокардіального сигналу в систолу наближаються один до одного, а сам міокард скорочується.

Чим вище від'ємне значення \% деформації (стрейна), тим краща функція даного сегменту міокарда. На схемі-«мішені» нормальний стрейн відзначається цифрою (в різних системах різних виробників колір може бути різним). Найбільш традиційна шкала подібна до кольорового картування: червоний — нормальний напрямок деформації, посвітлішання до рожевого — погіршення кінетики, ї̈ відсутність — блакитний спектр. Але треба орієнтуватися на цифру \% 


\section{Результати}

Порівняльний аналіз структурно-функціональних показників серця в групах пацієнтів, які перехворіли на COVID-19, та осіб без COVID-19 в анамнезі сприяв формуванню приблизної моделі «постковідного серця» (табл. 3, рис. 1) При однаковій товщині стінок ЛШ (ТМШП та ТЗСЛШ) діастолічний розмір та об'єм (КДР, КДО) ЛШ були достовірно вищими, ніж у групі порівняння $(p=0,0001)$, як і розмір ЛП $(p=0,03)$. Збільшення розміру ЛШ у діастолу обумовило достовірно більшу величину ММЛШ $(p=0,005)$ в групі тих, хто перехворів на COVID-19. Таким чином, отримано ознаки порівнянного тривалого перевантаження лівих відділів серця - компенсаторну структурну дилатацію лівих відділів серця у пацієнтів після COVID-19. Ці зміни не призвели до зниження скоротливої функції ЛШ фракція викиду (ФВ) залишилася однаковою в порівнюваних групах (див. рис. 1).

Середньодобова ЧСС, за даними хмЕКГ, у пацієнтів після перенесеного COVID-19 була вищою несуттєво - 75 проти 80 уд./хв, хоча достовірно ( $p=0,02)$. Кількість, як ШЕ, так і НШЕ, була більшою у 3-4 рази, ніж у пацієнтів без COVID-19 в анамнезі. Основну кількість екстрасистол реєстрували вдень, тоді, коли людина була активною фізично та психічно. Цей факт стосувався як ШЕ, так і НШС (табл. 4, рис. 2). Співвідношення денної кількості екстрасистол до нічної в обох групах представлені на рис 3. Достовірне підвищення ЦІ в групі постковідних пацієнтів разом зі зростанням середньодобової чСС демонструє порівнянну гіперсимпатикотонію у цієї групи пацієнтів, на тлі якої спостерігається денна аритмічна активність.

Епізоди зміщення сегменту ST на хмЕКГ зафіксовано у більшої половини пацієнтів після COVID-19 з кардіалгією в близькому анамнезі (протягом 6 міс після перенесеної інфекції) - у 65\% (39 пацієнтів), тоді як у пацієнтів групи порівняння цей показник

Таблиця 3 Порівняльні особливості геометрії лШ в групі пацієнтів, що перенесли COVID-19

\begin{tabular}{|c|c|c|c|}
\hline Показник & $\begin{array}{c}\text { Без COVID-19 } \\
(n=60)\end{array}$ & $\begin{array}{c}\text { Після COVID-19 } \\
(n=60)\end{array}$ & $\mathbf{p}$ \\
\hline ЛП, мм & $31(29 ; 34)$ & $34(31 ; 37)$ & 0,03 \\
\hline $\mathrm{KCP}, \mathrm{MM}$ & $31(28 ; 34)$ & $31(28 ; 33)$ & 0,92 \\
\hline КДР, мм & $45(40 ; 48)$ & $50(46 ; 52)$ & 0,0001 \\
\hline КД0, мл & $113(87 ; 135)$ & $133(112 ; 155)$ & 0,0001 \\
\hline $\mathrm{KCO}$, мл & $40(28 ; 48)$ & $41(32 ; 46)$ & 0,51 \\
\hline$\Phi \mathrm{B}, \%$ & $67(63 ; 69)$ & $66(62 ; 71)$ & 0,39 \\
\hline ТЗСЛШд, мм & $10(9 ; 11)$ & $9(9 ; 10)$ & 0,21 \\
\hline ТМШПд, мм & $10(9 ; 11)$ & $10(9 ; 10)$ & 0,45 \\
\hline ММЛШ, г & $138(106 ; 166)$ & $164(141 ; 179)$ & 0,005 \\
\hline Індекс ММЛШ, г/м² & $76(62 ; 86)$ & $85(77 ; 96)$ & 0,01 \\
\hline
\end{tabular}

В табл. 3-9: показники представлені у вигляді медіан і інтерквартильного розмаху (25-й і 75-й процентиль показника). Порівняння величин показників проведено за допомогою методів непараметричної статистики для двох непов'язаних виборок — за U-критерієм Манна - Уітні.

Рисунок 1 Порівняльні особливості геометріїЛШ в групах пацієнтів, що перенесли COVID-19, та тих, що не перехворіли

180

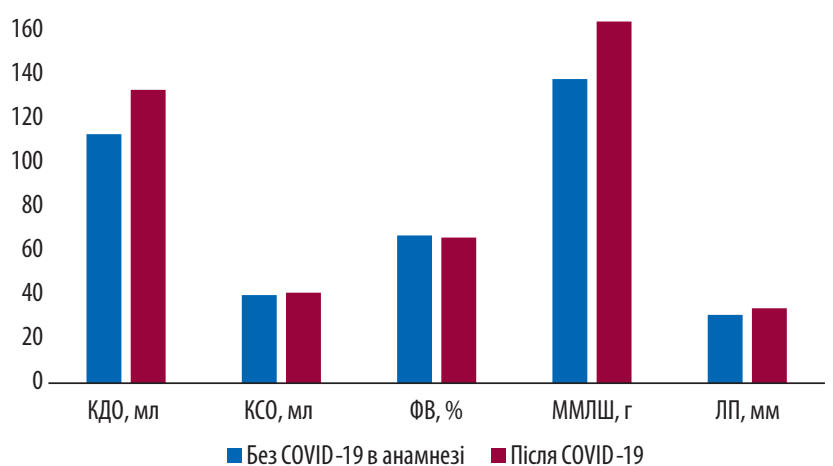

становив 33,3\% (20 пацієнтів). За структурою ішемічні зміни були достовірно більш значущими у перехворілих: за середньою кількістю епізодів патологічного зміщення сегменту ST на добу (6 проти $11 ; \mathrm{p}=0,008)$ та їх сумарною тривалістю (120 проти 310 c; $\mathrm{p}=0,02)$. Тенденцію до порівнянного збільшення мали також максимальний рівень депресії та максимальна тривалість епізоду депресії ST (табл. 5).

Таблиця 4 Порівняльний аналіз даних хмЕКГ у пацієнтів із наявністю та відсутністю COVID-19 в анамнезі протягом 6 міс: циркадний ритм, аритмії

\begin{tabular}{lccc}
\hline \multicolumn{1}{c}{ Показник } & $\begin{array}{c}\text { Без COVID-19 } \\
(\mathbf{n = 6 0 )}\end{array}$ & $\begin{array}{c}\text { Після COVID-19 } \\
(\mathbf{n = 6 0 )}\end{array}$ & $\mathbf{p}$ \\
\hline ЧСС, уд./Хв & $75(67 ; 81)$ & $80(69 ; 88)$ & 0,02 \\
\hline Кількість ШЕ за добу & $200(120 ; 418)$ & $820(650 ; 952)$ & $<0,0001$ \\
\hline ШЕд/ШЕн, од. & $1,1(1,0 ; 1,2)$ & $1,9(1,6 ; 2,4)$ & $<0,0001$ \\
\hline КільКість НШЕ за добу & $80(61 ; 140)$ & $325(216 ; 415) ;$ & 0,0001 \\
\hline НШЕд/НШЕн, од. & $1,2(0,84 ; 1,1)$ & $1,55(1,27 ; 2,0)$ & $<0,0001$ \\
\hline ЦІ, од. & $1,19(1,17 ; 1,28)$ & $1,25(1,22 ; 1,34)$ & 0,005 \\
\hline
\end{tabular}

Рисунок 2 Порівняльний аналіз даних хмЕКГу упацієнтів із наявністю та відсутністю COVID-19 в анамнезі протягом 6 міс: ЧСC, екстрасистолія

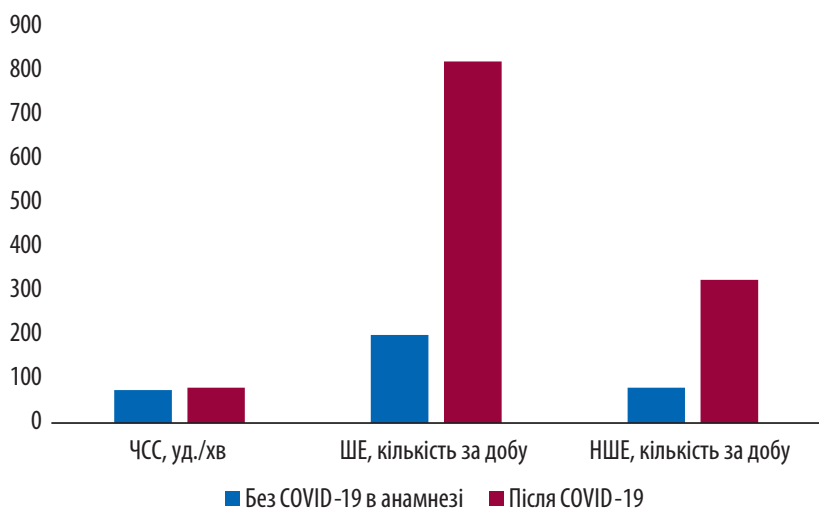

Рисунок 3 Порівняльний аналіз даних хмЕКГ у пацієнтів із наявністю та відсутністю COVID-19 в анамнезі протягом 6 міс: ЦЦ, співвідношення денних екстрасистол до нічних

3

2,5

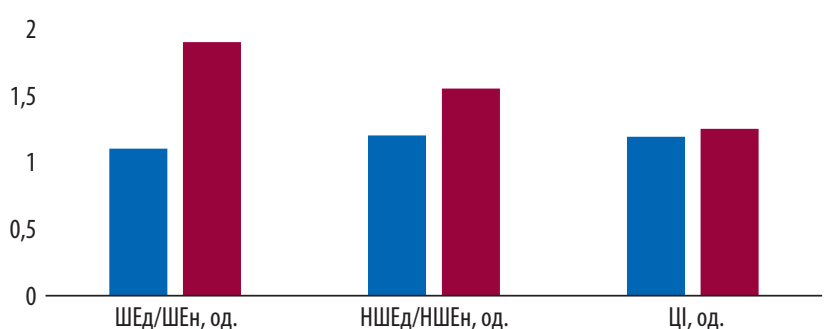

- Без COVID-19 в анамнезі п Після COVID-19

Таблиця 5 Порівняльний аналіз даних хмЕКГ у пацієнтів із наявністю та відсутністю COVID-19 в анамнезі протягом 6 міс: ішемія

\begin{tabular}{lccc}
\hline \multicolumn{1}{c}{ Показник } & $\begin{array}{c}\text { Без COVID-19 } \\
(\mathbf{n = 6 0 )}\end{array}$ & $\begin{array}{c}\text { Після COVID-19 } \\
\text { (n=60) }\end{array}$ & $\mathbf{p}$ \\
\hline Максимальний рівень депресії ST, мM & $1,9(1,5 ; 2,4)$ & $2,0(1,8 ; 2,4)$ & 0,17 \\
\hline $\begin{array}{l}\text { Середня кількість епізодів патологічно- } \\
\text { го зміщення ST за добу }\end{array}$ & $6,0(4,0 ; 9,0)$ & $11,0(5,0 ; 14,0)$ & 0,008 \\
\hline $\begin{array}{l}\text { Максимальна тривалість епізоду } \\
\text { патологічного зміщення ST, с }\end{array}$ & $25,0(15,5 ; 38,0)$ & $29,0(19,5 ; 45,0)$ & 0,12 \\
\hline $\begin{array}{l}\text { Сумарна тривалість патологічного } \\
\text { зміщення ST, с }\end{array}$ & $120,0(63,0 ; 310,0)$ & $310,0(90,0 ; 440,0)$ & 0,02 \\
\hline
\end{tabular}


Рутинна ЕхоКГ у стані спокою $є$ ненадійним методом оцінки недостатнього скорочення стінки серця внаслідок ішемії, якщо в цій зоні не було інфаркту, тобто за наявності живих ішемізованих кардіоміоцитів. СТЕхоКГ, або дослідження деформації міокарда у В-режимі, $\epsilon$ порівняно новою методикою оцінювання глобальної та регіонарної функції міокарда шлуночків, що набуває значного поширення [18-20]. СТЕхоКГ сьогодні доказово верифікована та використовується в діагностиці та оцінюванні ефективності лікування пацієнтів 3 ішемічною хворобою серця (IXC), оскільки має високу чутливість до виявлення доклінічної дисфункції міокарда навіть при нормальних результатах традиційної ЕхоКГ спокою у В-режимі. Доведена висока точність СТЕхоКГ у діагностиці конкретного басейну кровопостачання та її висока кореляція з даними коронарної ангіографії відносно рівня ураження при різних формах IXC, включаючи гострий коронарний синдром з/без елевації сегмента ST, вазоспастичну та мікроваскулярну стенокардію. Основні дані щодо СТЕхоКГ продемонстровані в табл. 1 та 2.

Зважаючи на відсутність у досліджуваних пацієнтів нестабільної стенокардії та високого класу стенокардії напруги, проте появу кардіалгії після перенесеної інфекції COVID-19, в схему дослідження включено не тільки хмЕКГ, а й СТЕхоКГ, яка завдяки точності та хорошій відтворюваності заслужено набула статусу «неінвазивної коронарографії».

Аналіз даних, отриманих за допомогою СТЕхоКГ, продемонстрував, що у пацієнтів, які перенесли COVID-19 із легким та середньо-тяжким перебігом, у постковідний період (до 6 міс) на тлі кардіалгії визначаються зони порівнянної ішемізації міокарда. Достовірно гірше скорочуються переважно базальні відділи передньої, передньо-септальної та латеральної стінок ЛШ, ніж у пацієнтів без інфекції в анамнезі, що відображено у табл. 6. На рис. 4 зображено схему «бичачого ока - мішені», що вказує на зони ішемії та відмічені червоним хрестиком (ліва частина рис. 4). Слід, однак, зазначити, що зменшення скорочення в основній групі на тлі перенесеної інфекції було порівнянним з групою осіб без COVID-19 в анамнезі, проте не суто патологічним: при нормальному загальному стрейні $-17 \%$ та менше $(-18 ;-20 ;-22 . . \%)$, зменшення було на $1-3$ од. максимально. Наприклад в базальному сегменті передньої стінки ЛШ в групі порівняння цей показник становив $-22,5(-25 ;-20)$, а в основній $-21(-23 ;-15)$ при $\mathrm{p}=0,057$, тобто у певної кількості пацієнтів після COVID-19 показник стрейну погіршувався до -15, а в цілому в групі становив -21 .

Достовірно нижчі показники поздовжнього зменшення базальних відділів передньої стінки та перегородки, а також базальних та середніх сегментів латеральної стінки (відмічені червоними хрестиками в лівій частині; рис. 4), не призвели до достовірного зниження показника загального стрейну (центр «мішені») порівняно з групою осіб без COVID-19 в анамнезі. У підсумку на тлі зниження локальної скоротливості базальних відділів стінок ЛШ, загальна поздовжня скоротливість, як і ФВ (циркулярна скоротливість), не зазнали змін.

На наступному етапі аналізу даних постає питання: чому не змінився загальний стрейн? Пояснення цього факту наочно продемонстровано на двох моделях ішемії на «мішенях» (рис. 5). Коли відмічається атеросклеротичне стенозування судини, стінка вражається подібно до трикутника з широкою основою в базальних відділах ЛШ та верхівкою, яка захоплює саме центр «мішені» (анатомічну верхівку серця). 3'являються величини стрейну з позитивним знаком та блідо-рожевого або голубого кольору. Схематично це можна представити так: стеноз $\rightarrow$ значне зменшення кровопостачання $\rightarrow$ гіпокінезія стінки $\rightarrow$ значне зменшення стрейну сегментів всієї стінки $\rightarrow$ загальний стрейн достовірно зменшується. Коли наявне мікросудинне ураження, наприклад внаслідок ендотеліальної дисфункції, змінюється стрейн переважно базальних відділів, частково середніх сегментів, проте до верхівки ішемія не доходить, скорочення зменшується на 2-3 од. (не в 2-3 рази, як при коронаростенозі), через це загальний стрейн залишається збереженим, подібно
Таблиця 6 Порівняльна оцінка показників СТЕхоКГ у пацієнтів, що перехворіли на COVID-19, та без COVID-19 в анамнезі

\begin{tabular}{|c|c|c|c|}
\hline Показник & $\begin{array}{l}\text { Без COVID-19 } \\
\quad(n=60)\end{array}$ & $\begin{array}{l}\text { Після COVID-19 } \\
(\mathrm{n}=60)\end{array}$ & $\mathbf{p}$ \\
\hline Базальний сегмент перегородки & $-20(-22 ;-17)$ & $-17(-20 ;-16)$ & 0,05 \\
\hline Середній сегмент перегородки & $-22(-26 ;-18)$ & $-22(-25 ;-20)$ & 0,98 \\
\hline Верхівковий сегмент перегородки & $-21(-24 ;-19)$ & $-21(-24 ;-19)$ & 0,96 \\
\hline Базальний сегмент передньої стінки & $-22,5(-25 ;-20)$ & $-21(-23 ;-15)$ & 0,057 \\
\hline Середній сегмент передньої стінки & 20) & $-23(-24 ;-17)$ & 0,26 \\
\hline Середній сегмент передньої стінки & $-22(-24 ;-20)$ & $-21,5(-26 ;-19)$ & 0,73 \\
\hline $\begin{array}{l}\text { Базальний сегмент передньо-перегоро- } \\
\text { дочної стінки }\end{array}$ & $-20(-22 ;-16)$ & $-19(-23 ;-15)$ & 0,99 \\
\hline $\begin{array}{l}\text { Середній сегмент передньо-перегоро- } \\
\text { дочної стінки }\end{array}$ & $-20(-22 ;-16)$ & $-20(-22 ;-17)$ & 0,75 \\
\hline Базальний сегмент латеральної стінки & $-17(-19 ;-14)$ & $-15(-12 ;-17)$ & 0,033 \\
\hline Середній сегмент латеральної стінки & $-20(-23 ;-17)$ & $-18(-21 ;-14$ & 0,047 \\
\hline Верхівковий сегмент латеральної стінки & $-18(-21 ;-15)$ & $-17(-21 ;-12)$ & 0,32 \\
\hline Базальний сегмент задньої стінки & $-19(-21 ;-15)$ & $-18(-21 ;-11)$ & 0,5 \\
\hline Верхівковий сегмент базальної стінки & $-18(-19 ;-15)$ & $-17(-19 ;-12)$ & 0,29 \\
\hline Базальний сегмент нижньої стінки & $-19(-21 ;-17)$ & $-18(-20 ;-14)$ & 0,18 \\
\hline Середній сегмент нижньої стінки & $-17,5(-20 ;-14)$ & $-17(-19 ;-16)$ & 0,74 \\
\hline Верхівковий сегмент нижньої стінки & $-17,5(-20 ;-15)$ & $-18(-20 ;-15)$ & 0,8 \\
\hline Загальний поздовжній стрейн & $-20(-21 ;-17)$ & $-18(-21 ;-16)$ & 0,58 \\
\hline
\end{tabular}

до того, як зображено на рис. 5 справа. Проте це два варіанти ішемії, і другий варіант відображує отриману нами у дослідженні модель «постковідного серця».

Будь-яка ішемія реагує на навантаження, тахікардія зменшує діастолу, зменшується кровопостачання ішемізованих ділянок. Якщо відбувається покращення кровопостачання після навантаження, то зміни зумовлені неорганічним ураженням, а $є$ функціональними і не потребують лікування.

Наступним етапом формування моделі «постковідного серця» стало проведення фізичного навантаження та спостереження за динамікою показників СТЕхоКГ. Пацієнти виконували пробу з фізичним навантаженням: присідали, віджималися або інтенсивно ходили до виникнення болю або дискомфорту в ділянці серця. Отримані дані представлені на рис. 4. Зліва повторюється отримана модель у стані спокою у пацієнтів після COVID-19, справа зображене «бичаче око - мішень» після навантаження: ішемія не тільки «повторила» ті самі базальні відділи, що були уражені до навантаження, а ще й поширилася на всю латеральну стінку, зменшивши і загальний поздовжній стрейн - хрестик в центрі «мішені».

Для коректного представлення моделі «постковідного серця» необхідно було отримати картину змін стрейну у осіб без COVID-19 в анамнезі не тільки у спокої, а й після навантаження (табл. 7). У цих пацієнтів до навантаження в цілому по групі достовірних відхилень від норми стрейну не виявлено. Навантаження висвітлило зміни скоротливості тільки в одному сегменті - базальному сегменті латеральної стінки: -17 (-20;

Рисунок 4 Схематичне зображення стінок ЛШ при СТЕХоКГ у вигляді «мішені» та відмічені зони ішемії в групі пацієнтів, що перехворіли на COVID-19, у стані спокою та після фізичного навантаження
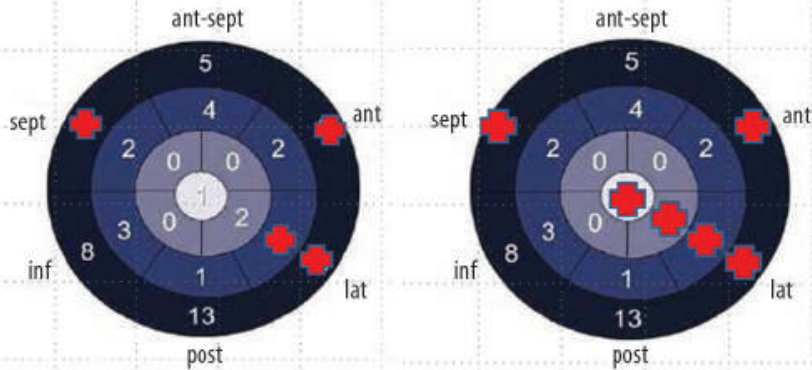
Рисунок 5 Порівняння моделі ішемії внаслідок коронаростенозу (зліва) та на тлі мікросудинних змін (справа)
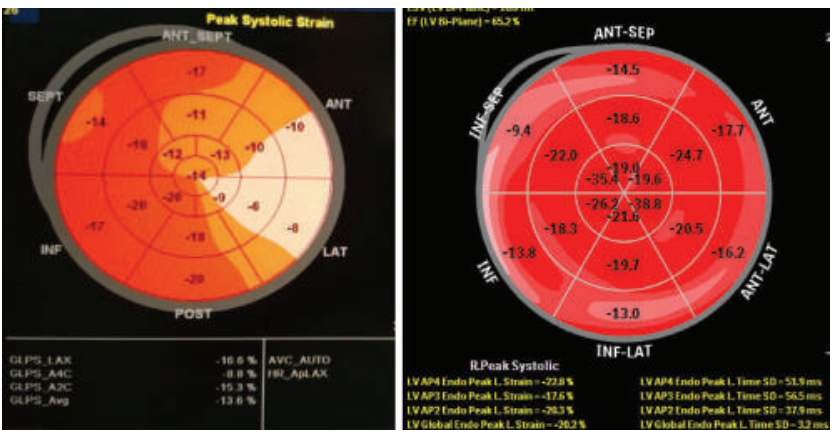

Таблиця 7 Результати навантажувальної СТЕхоКГ у пацієнтів без COVID-19 в анамнезі

\begin{tabular}{|c|c|c|c|}
\hline Показ & $\begin{array}{l}\text { Без COVID-19 } \\
(n=60)\end{array}$ & $\begin{array}{l}\text { Після COVID-19 } \\
(\mathrm{n}=60)\end{array}$ & $\mathbf{p}$ \\
\hline \multicolumn{4}{|c|}{ Оцінка динаміки показників СТЕхоКГ } \\
\hline Базальний сегмент перегородки & $-19(-22 ;-17)$ & $-19(-23 ;-17)$ & 0,77 \\
\hline Середній сегмент перегородки & $-21(-24 ;-19)$ & $-21(-24 ;-18)$ & 1,0 \\
\hline Верхівковий сегмент перегородки & $-20(-23 ;-19)$ & $-10(-23 ;-19)$ & 0,23 \\
\hline Базальний сегмент передньої стінки & $-21(-22 ;-15)$ & $-21(-22 ;-16)$ & 0,39 \\
\hline Середній сегмент передньої стінки & $-22(-24 ;-18)$ & $-22(-25 ;-17)$ & 0,39 \\
\hline Верхівковий сегмент передньої стінки & $-21(-2$ & $-21(-2$ & 0,6 \\
\hline $\begin{array}{l}\text { Базальний сегмент передньо-перегоро- } \\
\text { дочної стінки }\end{array}$ & $-23 ;-15)$ & $-19(-23 ;-15)$ & 0,21 \\
\hline $\begin{array}{l}\text { Середній сегмент передньо-септальної } \\
\text { стінки }\end{array}$ & $-19(-22 ;-15)$ & $-19(-22 ;-17)$ & 0,39 \\
\hline Середній сегмент латеральної стінки & $-16(-18 ;-9)$ & $-16(-18 ;-11)$ & 0,052 \\
\hline Базальний сегмент латеральної стінки & $-17(-20 ;-8)$ & $-18(-21 ;-11)$ & 0,006 \\
\hline Верхівковий сегмент латеральної стінки & $-17(-19 ;-12)$ & $-17(-20 ;-13)$ & 0,15 \\
\hline Базальний сегмент задньої стінки & $-17(-21 ;-9)$ & $-17(-21 ;-14)$ & 0,5 \\
\hline Середній сегмент задньої стінки & $-16(-18 ;-10)$ & $-16(-18 ;-11)$ & 0,33 \\
\hline Базальний сегмент нижньої стінки & $-18(-19 ;-14)$ & $-18(-21 ;-14)$ & 0,11 \\
\hline Середній сегмент нижньої стінки & $-18(-19 ;-15)$ & $-18(-19 ;-15)$ & 1,0 \\
\hline Верхівковий сегмент нижньої стінки & $-17(-20 ;-13)$ & $-17(-19 ;-15)$ & 0,79 \\
\hline Загальний поздовжній стрейн & $-19(-20 ;-17)$ & $-19(-21 ;-17)$ & 0,23 \\
\hline
\end{tabular}

-8) проти -18 $(-21 ;-11)(p=0,006)$, що суттєво відрізнялося від моделі навантаження у пацієнтів після COVID-19 (див. рис. 5). До речі, чому після COVID-19 постраждали переважно базальні сегменти стінок ЛШ, зрозуміло: мікросудинна ішемія субендокардіальних відділів внаслідок постковідного ендотеліїту. А от чому постраждали всі сегменти саме латеральної стінки на сьогодні не $\epsilon$ зрозумілим і потребує подальшого більш глибокого вивчення.

Результати лікування пацієнтів із кардіалгією після COVID-19 Сиднофармом в дозі 2 мг 2 рази на добу протягом 30 діб виявилися досить суттєвими та позитивними (табл. 8). Внаслідок відновлення кровопостачання покращилося скорочення і тих сегментів, які були ішемізовані до лікування, і тих, скоротливість яких була порівняно хорошою до лікування. Ці зміни відмічені червоними хрестиками на рис. 6 зліва.

Дані СТЕхоКГ підтвердилися і даними хмЕКГ: кількість паці$\epsilon$ тів із депресією ST після лікування Сиднофармом зменшилася майже у 3 рази, тоді як в групі, що лікувалася без застосування Сиднофарму у комплексній терапії, - з 30 до 23\% (було 9 із 30 пацієнтів із депресією ST, залишилося - 7) (рис. 7).

За даними хмЕКГ, достовірно змінилася й структура депреciї ST у тих пацієнтів, в яких ішемія залишилася після лікування: знизилися максимальний рівень депресії ST у мм та сумарна тривалість патологічного зміщення ST, мала тенденцію до зменшення тривалість максимального епізоду депресії ST (табл. 9). Таким чином, після лікування виявлено стабільний суттєвий антиішемічний ефект Сиднофарму як у зменшенні кількості пацієнтів

із інструментально доведеною ішемією, так і у зменшенні тривалості епізодів ішемії.

I головне: як змінилася клінічна картина після медикаментозного втручання? У групі, що отримувала Сиднофарм, залишилось лише 7\% пацієнтів із кардіалгією, в групі без Сиднофарму в програмі лікування - 33\%, тобто $1 / 3$ незадоволених або не повністю задоволених результатами лікування хворих (рис. 8).

Таблиця 8 Динаміка показників СТЕхоКГ в групі, що отримувала Сиднофарм

\begin{tabular}{lccc}
\hline Показник, \% & $\begin{array}{c}\text { До лікування } \\
(n=30)\end{array}$ & $\begin{array}{c}\text { Після лікування } \\
(n=30)\end{array}$ & $p$
\end{tabular}

Оцінка динаміки показників СТЕхоКГ

\begin{tabular}{|c|c|c|c|}
\hline Базальний сегмент перегородки & $-18(-20 ;-16)$ & $-19(-20 ;-18)$ & 0,043 \\
\hline Середній сегмент перегородки & $-19,5(-24 ;-17)$ & $-19,5(-23 ;-18)$ & 0,29 \\
\hline Верхівковий сегмент перегородки & $-19,5(-22 ;-18)$ & $-20(-22 ;-18)$ & 0,077 \\
\hline Базальний сегмент передньої стінки & $-22(-23 ;-18)$ & $-22(-23 ;-19)$ & 0,11 \\
\hline Середній сегмент передньої стінки & $-22(-24 ;-19)$ & $-22(-24 ;-19)$ & 0,041 \\
\hline Верхівковий сегмент передньої стінки & $-20(-23 ;-18)$ & $-20(-23 ;-18)$ & 0,22 \\
\hline $\begin{array}{l}\text { Базальний сегмент передньо-перегоро- } \\
\text { дочної стінки }\end{array}$ & $-17,5(-22 ;-16)$ & $-19(-22 ;-17)$ & 0,002 \\
\hline $\begin{array}{l}\text { Середній сегмент передньо-перегоро- } \\
\text { дочної стінки }\end{array}$ & $-17,5(-20 ;-16)$ & $-19(-20 ;-18)$ & 0,003 \\
\hline Базальний сегмент латеральної стінки & $-16,5(-19 ;-12)$ & $-18(-19 ;-16)$ & 0,001 \\
\hline Середній сегмент латеральної стінки & $-16(-20 ;-14)$ & $-18(-19 ;-17)$ & 0,001 \\
\hline Верхівковий сегмент латеральної стінки & $-19(-21 ;-16)$ & $-19(-21 ;-17)$ & 0,01 \\
\hline Базальний сегмент задньої стінки & $-17(-21 ;-16)$ & $-19(-21 ;-17)$ & 0,003 \\
\hline Середній сегмент задньої стінки & $-18(-19 ;-16)$ & $-18(-19 ;-17)$ & 0,016 \\
\hline Середній сегмент нижньої стінки & $-19(-20 ;-17)$ & $-18(-20 ;-17)$ & 0,18 \\
\hline Базальний сегмент нижньої стінки & $-19(-20 ;-16)$ & $-19(-20 ;-17)$ & 0,026 \\
\hline Верхівковий сегмент нижньої стінки & $-17(-19 ;-16)$ & $-17(-20 ;-16)$ & 0,07 \\
\hline Загальний поздовжній стрейн & $-19(-20 ;-17)$ & $-19(-20 ;-18)$ & 0,08 \\
\hline
\end{tabular}

Рисунок 6 Результат лікування Сиднофармом пацієнтів із кардіалгією після перенесеного COVID-19 (зліва — «мішень» до, справа - після лікування)
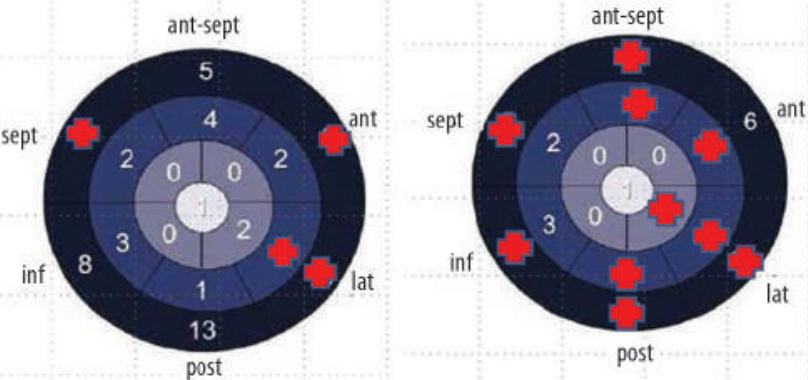

Рисунок 7 Результат лікування Сиднофармом пацієнтів із кардіалгією після перенесеного COVID-19 (зліва — «мішень» до, справа - після лікування)

Пацієнти $з$ кардіалгією до прийому Сиднофарму

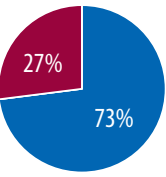

Пацієнти 3 кардіалгією до лікування

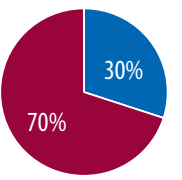

Пацієнти 3 кардіалгією, які застосовували Сиднофарм

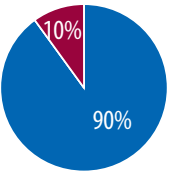

Пацієнти після лікування без застосування Сиднофарму

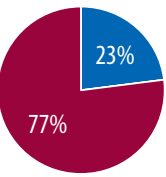


Таблиця 9 Результати лікування: порівняльний аналіз даних хмЕКГ у пацієнтів із COVID-19 анамнезі, що не отримували Сиднофарм, та застосовували його у комплексній терапії

\begin{tabular}{lccc}
\hline \multicolumn{1}{c}{ Показник } & $\begin{array}{c}\text { Без Сиднофарму } \\
\text { (n=30) }\end{array}$ & $\begin{array}{c}\text { Із Сиднофармом } \\
\text { (n=30) }\end{array}$ & p \\
\hline Максимальний рівень депресії ST, мM & $2,1(1,7 ; 2,4)$ & $1,9(1,5 ; 2,2)$ & 0,017 \\
\hline $\begin{array}{l}\text { Середня кількість епізодів патологічно- } \\
\text { го зміщення ST за добу }\end{array}$ & $11,0(5,0 ; 14,0)$ & $6,0(4,3 ; 9,3)$ & 0,008 \\
\hline $\begin{array}{l}\text { Максимальна тривалість епізоду } \\
\text { патологічного зміщення ST, с }\end{array}$ & $29,0(19,5 ; 45,0)$ & $25,0(15,5 ; 38,0)$ & 0,12 \\
\hline $\begin{array}{l}\text { Сумарна тривалість патологічного } \\
\text { зміщення ST, с }\end{array}$ & $310,0(90,0 ; 440,0)$ & $100,0(63,0 ; 210,0)$ & 0,002 \\
\hline
\end{tabular}

Рисунок 8 Результати лікування:динаміка кардіалгії в групах без Сиднофарму та з його застосуванням у програмі лікування

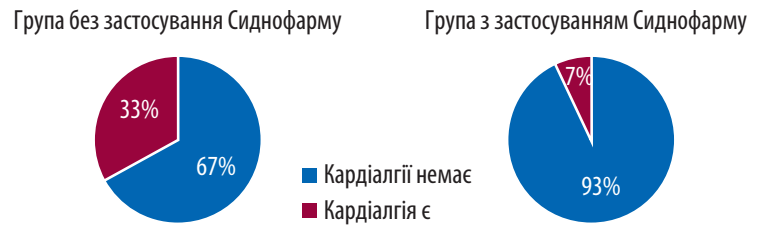

\section{Обговорення}

Молсидомін (Сиднофарм) чинить венодилататорну, антиагрегантну, анальгезивну та тривалу антиангінальну дію. Венодилататорна активність зумовлена виділенням після ряду метаболічних перетворень NO, що стимулює розчинну гуанілатциклазу, у зв'язку з цим молсидомін розглядається як донор NO. Накопичення циклічного гуанозинмонофосфату зумовлює розслаблення гладком'язових клітин судинної стінки. Зниження переднавантаження навіть без впливу на скорочуваність міокарда зумовлює відновлення порушеного у хворих із коронарною недостатністю співвідношення між потребою у кисні та його надходженням. Сиднофарм розширює уражені атеросклерозом, але здатні до дилатації великі епікардіальні коронарні артерії, покращує периферичний кровообіг.

Беручи до уваги отриману на I етапі модель «постковідного серця» - ураження базальних сегментів стінок ЛШ внаслідок мікросудинних субендокардіальних змін, вірогідно, за рахунок персистуючого ендотеліїту та вираженої ендотеліальної дисфункції, ефект тривалого застосування Сиднофарму у терапевтичній дозі (2 мг 2 рази на добу) виправдав всі очікування: зменшилися прояви ішемії та зникла кардіалгія у більшості пацієнтів після перенесеного COVID-19.

\section{Висновки}

1. Пацієнти, що перенесли COVID-19 протягом останніх 6 міс, мають відносно більші об'єми лівих відділів серця та ММлШ порівняно з тими, що не перехворіли. У них спостерігається відносна гіперсимпатикотонія з переважанням денної аритмічної активності.

2. За даними CTExоКГ, у пацієнтів, що перенесли COVID-19 та мають тривалий час кардіалгію, спостерігається зменшення локальної скоротливості переважно базальних сегментів стінок ЛШ внаслідок субендокардіальної мікроваскулярної ішемії.

3.У пацієнтів із постковідною кардіалгією виявлено суттєве зменшення як вираженості скарг, так і інструментальних даних проявів ішемії: кількості епізодів депресії сегменту ST (хмЕКГ) та покращення скоротливості переважно базальних та середніх відділів стінок ЛШ (СТЕхоКГ) внаслідок покращення їх кровопостачання на тлі лікування Сиднофармом в дозі 2 мг 2 рази на добу протягом 30 днів.

4. Сиднофарм - коронародилататор, донатор NO, ендотеліопротектор, антиангінальний та антиішемічний препарат, який застосовують переважно в лікуванні IXC, - можна рекомендувати призначати також в комплексній терапії пацієнтів із постковідним синдромом.

\section{Список використаної літератури/References:}

1. https://coronavirus.jhu.edu/map.html

2. Gladkac M.M., Maack Ch. (2020) The endothelium as Achilles' heel in COVID-19 patients. Cardiovasc. Res., 116(14): e195-e197.

3. Nägele M.P., Haubner B., Tanner F.C. et al. (2020) Endothelial dysfunction in COVID-19: Current findings and therapeutic implications. Atherosclerosis, 314: 58-62. doi: 10.1016/j.atherosclerosis.2020.10.014.

4. Buja L.M., WolfD.A., Zhao B. et al. (2020) The emerging spectrum of cardiopulmonary pathology of the coronavirus disease 2019 (COVID-19): Report of 3 autopsies from Houston, Texas, and review of autopsy findings from other United States cities. Cardiovasc. Pathol., 48: 107233.

5. Fox Sh.E., Akmatbekov A., Harbert J.L. et al. (2020) Pulmonary and cardiac pathology in African American patients with COVID-19: an autopsy series from New Orleans. Lancet, 8(7): P681-P686.

6. Bernard I., Limonta D., Mahal L.K., Hobman T.C. (2020) Endothelium Infection and Dysregulation by SARS-CoV-2: Evidence and Caveats in COVID-19. Viruses, 13(1): 29. doi: 10.3390/ v13010029.

7. Libby P., Lüscher Th. (2020) COVID-19 is, in the end, an endothelial disease. Eur. Heart J., 41(32): 3038-3044. https://doi.org/10.1093/eurheartj/ehaa623.

8. Ngai J.C., Ko F.W., Ng S.S. et al. (2010) The long-term impact of severe acute respiratory syndrome on pulmonary function, exercise capacity and health status. Respirology, 15(3): 543-550. doi: 10.1111/j.1440-1843.2010.01720.x.

9. Tay M.Z., Poh Ch.M., Rénia L. et al. (2020) The trinity of COVID-19: immunity, inflammation and intervention. Nat. Rev. Immunol., 20(6): 363-374. doi: 10.1038/s41577-020-0311-8.

10. Yende S., Kellum J.A., Talisa V.B. et al. (2019) Long-term Host Immune Response Trajectories Among Hospitalized Patients With Sepsis. JAMA Netw. Open, 2(8): e198686. doi: 10.1001/ jamanetworkopen.2019.8686.

11. Hartley C., Bavinger J.C., Kuthyar S. et al. (2020) Pathogenesis of Uveitis in Ebola Virus Disease Survivors: Evolving Understanding from Outbreaks to Animal Models. Microorganisms, 8(4): 594. doi: 10.3390/microorganisms8040594.

12. Wu F., Wang A., Liu M. et al. (2020) Neutralizing antibody responses to SARS-CoV-2 in a COVID-19 recovered patient cohort and their implications (https://www.medrxiv.org/content/ 10.1101/2020.03.30.20047365v2).

13. Gemelli Against COVID-19 Post-Acute Care Study Group (2020) Post-COVID-19 global health strategies: the need for an interdisciplinary approach. Aging Clin. Exp. Res., 11: 1-8.

14. Thornton J. (2020) Covid-19: the challenge of patient rehabilitation after intensive care. BMJ, 369: $\mathrm{m} 1787$.

15. O'Keefe J.B., Cellai M. (2020) Characterization of prolonged COVID-19 symptoms and patient comorbidities in an outpatient telemedicine cohort (https://www.medrxiv.org/content/10. 1101/2020.07.05.20146886v1)

16. Cheng H., Wang Y., Wang G.Q. (2020) Organ-protective Effect of Angiotensin-converting Enzyme 2 and its Effect on the Prognosis of COVID-19. J. Med. Virol., 92(7): 726-730.

17. Selyuk M.M., Kozachok M.M., Levkin I.M. et al. (2018) Influence of molsidomine (Sidnofarm) on central hemodynamic parameters and on exercise tolerance disorders in patients with stage Il arterial hypertension. Fam. Med., 3(77): 67-73. (In Ukr.).

18. Choi J.0., Cho S.W., Song Y.B. et al. (2009) Longitudinal $2 D$ strain at rest predicts the presence of left main and three vessel coronary artery disease in patients without regional wall motion abnormality. Eur. J. Echocardiogr., 10: 695-701.

19. Aggeli C., Felekos I., Tousoulis D. et al. (2013) Myocardial mechanics for the early detection of cardiac sarcoidosis. Int. J. Cardiol., 168(5): 4820-4821. https://doi.org/10.1016/j.ijcard.2013.07.010.

20. Biering-Sørensen T., Jensen J.S., Pedersen S.H., Galatius S. (2016) Regional Longitudinal Myocardial Deformation Provides Incremental Prognostic Information in Patients with STSegment Elevation Myocardial Infarction. PLOS ONE, 11(6): e0158280.

\section{Post-COVID-19 changes}

\section{in the structure of the heart and} the effectiveness of the vasodilator Sidnofarm (results of own research)

\section{N.Yu. Osovska, L.A. Oliynyk}

Vinnitsa National Medical University named after M.I. Pirogov, Vinnytsia, Ukraine

Abstract. The aim is to compare the changes in the structural and functional state of the left ventricular myocardium in patients after COVID-19 and to determine the antianginal and antiischemic activity 
of molsidomine (Sidnopharm) in this category of patients. Object and methods of research. We examined 120 persons aged $58 \pm 8.23$ years ( $48.4 \%$ of women and $51.6 \%$ of men), 60 of whom relapsed to COVID-19 and had complaints from the cardiovascular system, including cardialgia. All patients in the complex treatment of major diseases received statins, renin-angiotensin-aldosterone system blockers, antiplatelet agents and other prescribed therapy. Patients with COVID-19 were divided into two groups (30 individuals). Sidnopharm at a dose of $2 \mathrm{mg} 2$ times a day for 1 month was added in the treatment program of the 1st (main) group, the 2nd (comparison group) received any antianginal drugs, except for nitrates of prolonged action. Results. Patients who underwent COVID-19 in the past 6 months were found to have relatively larger left heart volumes and left ventricular myocardial mass compared to those who did not become ill. They have relative hypersympathicotonia with a predominance of daytime arrhythmic activity. According to speckletracking echocardiography, patients with COVID-19 and long-term

\section{Відомості про авторів:}

Осовська Н.Ю. - доктор медичних наук, професор, завідувач кафедри терапевтичних дисциплін та сімейної медицини факультету післядипломної освіти Вінницького національного медичного університету імені М.І. Пирогова, Вінниця, Україна.

Олійник Л.А. — лікар вищої категорії, аспірант кафедри терапевтичних дисциплін та сімейної медицини факультету післядипломної освіти Вінницького національного медичного університету імені М.І. Пирогова, Вінниця, Україна.

\section{Адреса для кореспонденції:}

Осовська Наталія Юріївна

21018, Вінниця, вул. Пирогова, 56 cardialgia have a decrease in local contractility of predominantly basal segments of the left ventricular wall due to subendocardial microvascular ischemia. Patients with post-COVID-19 cardialgia showed a significant reduction in both the severity of complaints and instrumental data of ischemia: the number of episodes of depression of the ST segment (according to Holter monitoring) and improved contractility of mainly basal and middle sections of the walls of the left ventricle (according to speckle-tracking echocardiography) due to the improvement of their blood supply on the background of treatment with Sidnopharm at a dose of $2 \mathrm{mg} 2$ times a day for 30 days. Conclusion. Sidnopharm - coronary dilator, nitric oxide donor, endothelial protector, antianginal and anti-ischemic drug, which is used mainly in the treatment of coronary heart disease - can also be recommended to prescribe in the treatment of patients with postCOVID-19 syndrome.

Key words: COVID-19, post-COVID-19 syndrome, cardialgia, molsidomine, Sidnopharm.

\section{Information about the authors:}

Osovska N.Yu. - doctor of medical sciences, professor, head of the department of therapeutic disciplines and family medicine of the faculty of postgraduate education of Vinnytsia National Medical University named after MI Pirogov, Vinnytsia, Ukraine.

Oliynyk L.A. — doctor of the highest category, graduate student of the Department of Therapeutic Disciplines and Family Medicine, Faculty of Postgraduate Education, Vinnytsia National Medical University named after MI Pirogov, Vinnytsia, Ukraine.

\section{Address for correspondence:}

Natalia Osovska

21018, Vinnytsia, Pirogov str., 56 